\title{
DAMPAK BELAJAR DARI RUMAH
}

\author{
Ervi Revilda ${ }^{1}$, Nur Hadi ${ }^{2}$, Joan Hesti Gita Purwasih ${ }^{3}$ \\ 'Prodi Pendidikan Sosiologi, Universitas Negeri Malang \\ Correspondence email: revildaervi3@gmail.com \\ ${ }^{2}$ Prodi Pendidikan Sosiologi, Universitas Negeri Malang \\ Correspondence email: nur.hadi.fis@um.ac.id \\ 3 Prodi Pendidikan Sosiologi, Universitas Negeri Malang \\ Correspondence email: joan.hesti.fis@um.ac.id
}

\begin{abstract}
Abstrack
Work This research discusses online learning or commonly known as BDR (Learning from Home). The purpose of this study is to analyze the impact of BDR implementation. As well as explaining how elementary school students who work while attending school during the BDR implementation. The research method used is qualitative research with a case study approach. Data collection used observation and interviews with 2 elementary school students (1 grade 3 student and 1 grade 5 student who worked as a fishing jockey at Fishing Pond X, 2 guardians, and 3 teachers from the school. The validity of the data used triangulation. The results showed that the implementation of learning was carried out in accordance with the Covid 19 emergency curriculum which was carried out based on the UKRK indicator (urgency, continuity, relevance, and usability), where learning could be carried out efficiently according to the abilities of school residents. $\mathrm{K}-13$ Covid 19 is still being found. technical in the field, namely the large number of human resources who are clueless or technologically illiterate, while in the teaching and learning process teachers are still not maximized in delivering material. With the existence of various BDR schools, schools have solutions to overcome these problems, namely by holding offline meetings for students whose learning facilities are inadequate as well There was a home visit for students who had no news during the BDR implementation. The emergence of elementary school level students who work because they work on their own initiative and help earn a living for their parents and channel their talents
\end{abstract}

\section{Keywords:}

pandemic, child, learn from home

\begin{abstract}
Abstrak
Penelitian ini membahas mengenai pembelajaran secara daring atau biasa disebut dengan BDR (Belajar dari Rumah). Tujuan dari penelitian ini yaitu menganalisis dampak dari pelaksanaan BDR. Serta menjelaskan bagaimana siswa sekolah dasar yang bekerja sambil sekolah dimasa pelaksanaan BDR. Metode penelitian yang digunakan yakni menggunakan jenis penelitian kualitatif dengan pendekatan studi kasus. Pengumpulan data menggunakan observasi dan wawancara pada 2 peserta didik tingkat Sekolah Dasar (1 peserta didik kelas 3 dan 1 peserta didik kelas 5 yang bekerja sebagai Joki Pemancing di Kolam Pancing X, 2 wali murid, serta 3 guru dari pihak sekolah. Validitas data menggunakan triangulasi sumber. Hasil penelitian menunjukkan bahwa pelaksanaan pembelajaran dilakukan sesuai dengan kurikulum darurat Covid 19 yang dilaksanakan berdasarkan indicator UKRK (urgensi, kontinuitas,relevansi, dan keterpakaian),dimana pembelajaran bisa dilakukan secara efisien sesuai dengan kemampuan warga sekolah. Pelaksanaan BDR yang disesuaikan dengan kurikulum darurat K-13 Covid 19 masih ditemukan kendala-kendala teknis di lapangan,yaitu banyaknya SDM yang gaptek atau gagap teknologi, sedangkan dalam proses belajar mengajar guru masih belum maksimal dalam menyampaikan materi. Dengan adanya berbagai kendala BDR sekolah memiliki solusi untuk mengatasi kendala-kendala tersebut yakni dengan mengadakan pertemuan offline bagi peserta didik yang fasilitas belajarnya tidak memadai serta adanya homevisit bagi peserta didik yang tidak ada kabar selama pelaksanaan BDR. Munculnya peserta didik tingkat Sekolah Dasar yang bekerja dikarenakan ia bekerja atas inisiatif sendiri dan membantu mencari nafkah orang tuanya serta menyalurkan bakat mereka.
\end{abstract}


Kata Kunci

pandemi, anak, belajar dari rumah

\section{A. PENDAHULUAN}

Awal mula pandemi di Indonesia terjadi pada bulan Maret 2020, pada dua orang yang terpapar Covid-19. Penyebaran virus yang sangat cepat tidak dapat dibendung dalam waktu kurang lebih satu minggu telah menyebar ke seluruh provinsi di Indonesia, terutama pada provinsi DKI Jakarta, Jawa barat, dan Jawa tengah '. Untuk mencegah penyebaran Covid 19 semakin meluas, Jokowi sebagai Presiden Indonesia langsung melakukan pres conference untuk menghimbau kepada seluruh warga Indonesia untuk melaksanakan seluruh kegiatan dari rumah ${ }^{2}$.

Menindaklanjuti hal tersebut, Kemendikbud mengeluarkan Surat Edaran mengenai Pembelajaran secara Daring dan Bekerja dari Rumah pada Hari Selasa, 17 Maret 2020, School from home di Indonesia mulai diberlakukan secara serentak ${ }^{3}$. Dalam Surat Edaran dijelaskan mengenai pelaksanaan Belajar Dari Rumah (BDR) yang dijalankan sama seperti biasa (sekolah offline), tidak mempengaruhi kehadiran dan tidak mengurangi kinerja ${ }^{4}$. Dalam edaran itu disebutkan juga mengenai opsi sarana pembelajaran yang bisa digunakan oleh para pendidik dan peserta didik dalam menunjang belajar dari Rumah. Berdasarkan Surat Edaran dari Kemendikbud tersebut seluruh jenjang Pendidikan dari Paud, TK/RA,

${ }^{1}$ (Satgas Covid-19, 2020)

2 (CNN Indonesia 2020)

3 (Kemendikbud, 2020)

${ }^{4}$ Sir John Daniel, "Education and the COVID-19 Pandemic," Prospects, 2020, https://doi.org/10.1007/s11125-020-09464-3.

5 Indah Pratiwi and Bakti Utama, "KESENJANGAN KUALITAS LAYANAN
SD/MI, SMP/MTS, SMA/MA, hingga Perguruan Tinggi sederajat di haruskan untuk melaksanakan BDR.

Berdasarakan Pratiwi and Utama ${ }^{5}$ pelaksanaan BDR disetiap wilayah berbeda-beda, ada yang berjalan dengan baik sesuai anjuran pemerintah dan ada yang melaksanakan sesuai dengan kemampuan wilayahnya. Pelaksanaan BDR akan berjalan dengan baik sesuai anjuran pemerintah di wilayah yang memiliki (1) akses internet dan (2) perangkat digital yang memadai serta (3) keterampilan guru maupun peserta didik dalam menggunakan perangkat digital. Di wilayah yang tidak memiliki salah satu maupun seluruh komponen dari tiga komponen yang disebutkan, mereka melaksanakan BDR dengan caranya sendiri; ada yang melaksanakan hanya penugasan via WA, ada yang melakukan pembelajaran di rumah gurunya, dan ada yang melakukan BDR dengan memanfaatkan TV/radio untuk penugasan.

Keberhasilan pelaksanaan BDR tidak hanya diukur dari ketersediaan akses internet dan perangkat digital, melainkan diukur dari kesiapan guru untuk menyediakan materi, media, maupun pengambilan nilai yang tepat sesuai dengan kondisi peserta didik di rumah masing masing serta kesiapan orang tua untuk mendampingi anaknya belajar dari rumah. Mutaqinah dan Hidayatullah $^{6}$ menyebutkan kendala

PENDIDIKAN DI INDONESIA PADA MASA DARURAT COVID-19: TELAAH DEMOGRAFI ATAS IMPLEMENTASI KEBIJAKAN BELAJAR DARI RUMAH," Jurnal Kependudukan Indonesia, 2020, https://doi.org/10.14203/jki.voio.539.

${ }^{6}$ Mutaqinah and Hidayatullah (2020) 
yang dihadapi guru selain keterbatasan akses internet yaitu kesulitan untuk mengontrol peserta didik. Selain itu, ia juga menjelaskan dalam proses pelaksanaan BDR tidak semua orang tua dapat mendampingi anaknya karena orang tua kesulitan dalam mengatur waktu antara bekerja di rumah dan mendampingi anaknya BDR. Padahal dalam pelaksanaan BDR ini, peran orang tua ialah hal yang utama dalam mendampingi anaknya, karena pada dasarnya dalam penerapan BDR orang tua lah yang menggantikan peran guru di sekolah untuk mendidik dan membimbing peserta didik dalam mengerjakan tugas-tugas sekolah ${ }^{7}$.

Pendampingan orang tua yang kurang dalam pelaksanaan BDR ditemukan juga pada keluarga yang mengarahkan anaknya untuk bekerja mencari uang untuk membantu orang tua dan menambah pengalaman hidup, studi kasus pada keluarga joki pemancing kecil. Maka dari itu, peneliti ini tertarik untuk mengetahui bagaimana pelaksanaan BDR yang dijalankan oleh anak tingkat Sekolah Dasar selama ini sehingga ia juga bisa bekerja ditengah-tengah mereka focus untuk belajar.

Penelitian ini menggunakan metode kualitatif dengan pendekatan studi kasus tunggal ${ }^{8}$ untuk menggali lebih dalam dan spesifik bagaimana pelaksanaan BDR dan kenapa anak tingkat SD itu bekerja sebagai joki

7 Inom Nasution and Suharian Suharian,
"PERAN ORANG TUA TERHADAP ANAK
DALAM PROGRAM BELAJAR DARI RUMAH DI
MASA PANDEMI COVID-19," Visipena, 2020,
https://doi.org/10.46244/visipena.vili2.1154;
Anita Wardani and Yulia Ayriza, "Analisis
Kendala Orang Tua Dalam Mendampingi Anak
Belajar Di Rumah Pada Masa Pandemi Covid-
19," Jurnal Obsesi : Jurnal Pendidikan Anak Usia
Dini, https://doi.org/10.31004/obsesi.v5i1.705. pemancing. Pengumpulan data dilakukan dengan cara observasi, wawancara dan triangulasi sumber. Wawancara dilakukan kepada kepada 2 peserta didik tingkat Sekolah Dasar (1 peserta didik kelas 3 dan 1 peserta didik kelas 5) yang bekerja sebagai Joki Pemancing di Kolam Pancing $\mathrm{X}, 2$ walipeserta didik, serta 1 guru dari pihak sekolah. Wawancara tersebut dilakukan untuk memperjelas bagaimana pelaksanan BDR dilihat dari 3 pihak (guru, orang tua, dan peserta didik) serta mempermudah analisis terkait dampak pelaksanaan BDR.

Peneliti menggunakan Teori Konstruksi Sosial sebagai unit analisisis. Menurut Peter L Berger dan Thomas Luckman ${ }^{9}$ konstruksi sosial memandang proses sosial malalui tindakan dan interaksi dimana individu atau sekelompokindividu, menciptakan secara terus-menerus suatu realitas yang dimiliki dan dialami bersama secara objektif, dan menpunyai kehendak bebas sebagai manusia. Sebagaimana kenyataan objektif mempengaruhi kembali manusia melalui proses internalisasi. Dengan begitu Berger dan Luckman memiliki cara pandang mengenai kenyataan sosial yang sebetulnya merupakan prosuk manusia yang dibangun secara sosial dan sosiologi pengetahuan melalui eksternalisasi, sehingga terbentuklah sebuah pembiasaan tradisi atau budaya. Berdasarkan hal tersebut artikel ini akan

\footnotetext{
8 Trista Hollweck, "Robert K. Yin. (2014). Case Study Research Design and Methods (5th Ed.). Thousand Oaks, CA: Sage. 282 Pages.," The Canadian Journal of Program Evaluation, 2016, https://doi.org/10.3138/cjpe.30.1.108.

9 Poloma Margaret, "Sosiologi Kontemporer," Jakarta: PT. Raja Grafindo Persada, 2003; Aimie Sulaiman, "MEMAHAMI TEORI KONSTRUKSI SOSIAL PETER L. BERGER,” Society, 2016, https://doi.org/10.33019/society.v4i1.32.
} 
menjelaskam proses terjadinya peserta didik yang memilih bekerja dalam pelaksanaan BDR tanpa mengesampingkan pembelajaran.

\section{B. HASIL DAN PEMBAHASAN}

Berdasarkan hasil pengumpulan data berikut pemaparan terkait

\section{B.1 Impelementasi pembelajaran dari Rumah}

Pembelajaran dari rumah mulai diberlakukan sejak semester ganjil tahun ajaran 2020/2021. Pemerintah menganjurkan pembelajaran dilakukan secara daring atau secara mandiri dari rumah dengan dibimbing orang tua sebagai pembimbing atau pendamping anak ketika belajar dirumah. BDR dilakukan karena adanya kebijakan pemerintah yang mengantisipasi persebaran pandemic penyebaran Covid-19 ${ }^{10}$. Dalam pelaksanaannya masih masih proses adaptasi, jadi timbul beberapa masalah sebagai berikut:

"Pada awal pemberlakuan BDR guru masih beradaptasi dengan cara pemberian materi dengan pemilihan media yang tepat sesuai dengan kemampuan fasilitas yang disediakan orang tua dan kondisi umum dari walipeserta didik ${ }^{11}$."

Adanya kebijakan BDR guru harus menyesuaikan diri dengan kemampuan siswa dan walipeserta didik sehingga dengan adanya BDR ini guru harus ekstra dalam menyesuaikan diri guna mencapai tujuan pembelajaran.

Pada proses adaptasi itu timbul beberapa masalah seperti yang

\footnotetext{
${ }^{10}$ Kemendikbud, "SE Mendikbud: Pembelajaran Secara Daring Dan Bekerja Dari Rumah Untuk Mencegah Penyebaran Covid-19."

"Hasil wawancara dengan Pak SH

${ }^{12}$ Hasil wawancara dengan $\mathrm{Bu} \mathrm{S}$ salah satu guru di MI

${ }^{13}$ Debora J. Bell et al., "Health Service Psychology Education and Training in the Time of COVID-
}

diutarakan oleh informan sebagai berikut tidak semua orang tua dapat memfasilitasi secara lengkap karena rata-rata orang tua / walipeserta didik di MI itu berpenghasilan pas-pas an ${ }^{12}$. Sehingga ada beberapa dari wali murid hanya mampu untuk mencukupi kebutuhan sehari-hari. Sehingga hal tersebut berkorelasi pada kemampuan wali murid dalam memberikan fasilitas pendukung sekolah seperti handphone. Sehingga ada beberapa aspek masalah dalam BDR seperti siswa yang harus bergantian menggunakan handphone orang tua, terbatasnya kemampuan untuk membeli kuota karena dalam pelaksanaannya bisa setiap hari melakukan BDR, banyaknya siswa yang kurang paham dengan materi yang dishare oleh guru ${ }^{13}$. Hal ini sesuai dengak penyataan informan yaitu:

"Dalam pelaksanaan tatap muka mereka sering susah dalam memahami materi apalagi kalau di rumah dengan kondisi orang tua yang tidak siap mendampingi anaknya belajar. Dengan begitu sekolah mengadakan pembelajaran tatap muka secara bergantian tiap kelas setiap minggunya dan pembelajaran selama di rumah lebih ke penugasan untuk mengerjakan buku tema dan test online selama semester 1 "14.

Hambatan yang dirasakan guru semasa pelaksanaan BDR $^{15}$ yaitu pemakaian aplikasi pembelajaran, jaringan internet dan handphone, pengelolaan pembelajaran, penilaian, serta pengawasan. Didalam berbagai macam

19: Challenges and Opportunities," American Psychologist, 2020, https://doi.org/10.1037/ampoooo673.

${ }^{14} \mathrm{Hasil}$ wawancara dengan $\mathrm{Bu} \mathrm{S}$ salah satu guru di MI

15 Rigianti (2020) 
hambatan tersebut, pelaksanaan BDR ini menghasilkan peserta didik yang lebih mandiri dan membentuk motivasi sebagai sarana belajar untuk belajar merupakan salah satu keberhasilan untuk membentuk perilaku social distancing, sehingga dampaknya dapat meminimalisir munculnya keramaian yang berpotensi memacu penyebaran covid-19 di lingkungan sekolah ${ }^{16}$.

Halangan yang sedang dirasakan guru semasa BDR adalah pemakaian aplikasi pembelajaran, jaringan internet, dan peranti elektronik atau gadget, pengelolaan pembelajaran, penilaian, serta pengawasan. Didalam berbagai macam halangan tersebut, proses BDR ini menghasilkan peserta didik yang memiliki tingkat kemandirian dan membentuk motivasi sebagai sarana belajar adalah sebagai salah satu usaha yang baik dalam membentuk perilaku social distancing, dampaknya yaitu mengurangi munculnya keadaan yang ramai sehingga sering dianggap dapat memacu peningkatan penyebaran covid-19 di lingkungan sekolah

Namun untuk membuat peserta didik lebih mandiri dan menciptakan motivasi untuk belajar, peniliti masih belum setuju. Hal ini dikarenakan temuan di lapangan ada walipeserta didik yang mengeluh tentang Pembelajan BDR membuat anak mereka menjadi malas, berikut pernyataannya.

"anak saya itu kalau disuruh belajar secara daring sangat sulit. Apalagi kalau disuruh membaca dulu materi yang sudah diberikan sama gurunya lalu nanti disuruh

\footnotetext{
${ }^{16}$ Jurnal Pendidikan Administrasi Perkantoran, Oktafia Ika Handarini, and Siti Sri Wulandari, "Pembelajaran Daring Sebagai Upaya Study From Home (SFH) Selama Pandemi Covid 19," Jurnal Pendidikan Administrasi Perkantoran (JPAP), vol. 8, July 17, 2020, https://journal.unesa.ac.id/index.php/jpap.
}

mengerjakan sulitnya minta ampun. Akan tetapi kalau main handphone betah. Jadi inisiatif pada saat mendampingi anak sekolah saya yang membaca materinya sama sedikit-sedikit menjelaskan dan nanti kalau ada tugas saya yang mendekte jawabannya, anak saya yang nulis. Soalnya saya tidak telaten untuk mendampingi anak BDR dan waktunya tidak banyak untuk itu. Karena banyak juga yang harus dikerjakan, seperti mencuci baju, memasak. " ${ }_{17}$

Berdasasarkan pernyataan tersebut, orang tua peserta didik masih belum siap melakukan pendampingaan terhadap anaknya dalam melakukan peran guru di dirumah sama seperti yang diungkapkan oleh Inom Nasution dan Suharian mengenai peran orang tua terhadap anak dalam program belajar dari rumah di masa Pandemi Covid $19^{18}$.

Selain itu, dalam pelaksanaan BDR di semester ganjil Tahun ajaran 2020/2021 kurikulum yang dipakai masih kurikulum K-13 yang memiliki kompetensi yang kompleks. Tidak heran jika guru dalam melaksanakan pembelajaran daring sering memberikan tugas yang banyak. Hal tersebut dilakukan agar kompentensi dasar mata pelajaran terselesaikan. Dan dampaknya bagi peserta didik ialah yang didapatkan dalam pelaksanaan BDR hanya pemenuhan kewajiban

\footnotetext{
17 Hasil wawancara dengan Ibu S W selaku orangtua A (peserta didik kelas 3)

${ }^{18}$ Nasution and Suharian, "PERAN ORANG TUA TERHADAP ANAK DALAM PROGRAM BELAJAR DARI RUMAH DI MASA PANDEMI COVID-19."
} 
untuk mengerjakan dan tidak memahami apa yang dipelajari ${ }^{19}$.

Menanggapi permasalahan yang terjadi selama BDR pemerintah terutama Kemendikbud mengeluarkan kurikulum darurat sebagai langkah fleksibel untuk satuan pendidikan memilih dan melaksanakan kurikulum yang fleksibel sesuai dengan kebutuhan $^{20}$. Maka dari itu, pada pelaksanaan Semester Gasal 2020-2021 beban belajar dikurangi dan disesuaikan dengan kemampuan dan fasilitas peserta didik. "Pengurangan beban belajar dilakukan oleh masing-masing guru mata pelajaran dan harus sesuai panduan. Ada panduannya untuk pengurangann beban belajar harus sesuai dengan kriteria UKRK. Urgensi, Kontinuitas, Relevansi, dan Keterpakaian."21 Apalagi sekolah ini berbasis madrasah ${ }^{22}$, kurikulum yang digunakan berpacu pada 2 kurikulum yaitu kurikulum dari kemendikbud dan kurikulum dari kemenag yang difokuskan pada KD 1 dan KD 2. Jadi pemilihan KD Essensial di sekolah ini difokuskan pada penerapan KD 1 dan KD 2 yang disinkronkan dengan KD 3 dan KD 4 yang lolos kriteria UKRK.

19 Bell et al., "Health Service Psychology Education and Training in the Time of COVID19: Challenges and Opportunities."

20 "Kementerian Pendidikan Dan Kebudayaan » Republik Indonesia,” accessed March 1, 2021, https://www.kemdikbud.go.id/main/blog/2020 /o8/kemendikbud-terbitkan-kurikulumdarurat-pada-satuan-pendidikan-dalamkondisi-khusus.

${ }^{21}$ Hasil wawancara dengan Pak SH selaku waka kurikulum dan guru di MI

22 Jurnal Ilmu et al., “J I A I," Ta’lim 2, no. 2 (October 30, 2020): 1-12, http://journal.uml.ac.id/TL/article/view/206.

23 Bell et al., "Health Service Psychology Education and Training in the Time of COVID19: Challenges and Opportunities."

24 "Belajar Mandiri: Pembelajaran Daring Di Tengah Pandemi Covid-19 - Sri Gusty, Nurmiati
Pelaksanaan pembelajaran pada Semester Gasal menerapkan kurikulum darurat merupakan cara yang tepat. Hal ini dikarenakan belajar dari rumah (BDR) yang dilakukan secara mandiri bertujuan untuk memberikan kesempatan kepada peserta didik untuk menambah makna pengalaman belajar tanpa adanya beban guna menyelesaikan indicator kompetensi untuk kenaikan kelas maupun kelulusan; peserta didik diberikan ketrampilan hidup yang dapat digunakan dalam kehidupannya mengenai Pandemic Covid 19 ${ }^{23}$; guru memberikan tugas yang beranekaragam dengan mempertimbangkan perbedaan kemampuan setiap peserta didik dan fasilitas belajar; dan pemberian timbal balik terhadap kerja siswa berdasarkan mutu $^{24}$. Keadaan ini senada dengan yang telah disampaikan guru di Madrasah

"Pembelajaran disemester gasal ini menggunakan kurikulum K-13 yang disesuaikan dengan Pandemi mbak, pelaksanaannya lebih fleksibel dan bisa diterima oleh peserta didik. disekolah memakai LKS sebagai buku ajar" ${ }_{25}$

Nurmiati, Muliana Muliana, Oris Krianto Sulaiman, Ni Luh Wiwik Sri Rahayu Ginantra, Melda Agnes Manuhutu, Andriasan Sudarso, Natasya Virginia Leuwol, Apriza Apriza, Andi Arfan Sahabuddin, Puji Hastuti, Akbar Yuli Setianto, Tia Metanfanuan, Lulu Jola Uktolseja, Jamaludin Jamaludin, Sherly Gaspersz, Karwanto Karwanto, Erni Rante Bungin, Samuel Y. Warella - Google Buku," accessed March 1, 2021,

https://books.google.co.id/books?hl=id\&lr=\&id $=$ HSz7DwAAQBAJ\&oi=fnd\&pg=PA85\&dq=kend ala+pembelajaran+daring\&ots=QndJElBiNi\&sig $=8 \mathrm{NxfY}$ 1JzDChgHvcYGBLjotPQVU8\&redir_esc $=$ $\mathrm{y} \# \mathrm{v}=$ onepage \& $\mathrm{q}=$ kendala pembelajaran daring\& $\mathrm{f}=$ false.

${ }^{25}$ Hasil wawancara dengan Bu S salah satu Guru di MI 
didukung dengan pernyataan walipeserta didik

"lebih baik BDR yang sekarang, tidak terlalu membebani orang tua dalam mendampingi belajar, tidak tertalu menghabiskan banyak kuota karena ada sebagian guru yang menggunakan LKS sebagai bahan ajar dan penilaiannya"26

Berdasarakan acuan Kurikulum yang terbaru pelaksanaan pembelajaran disesuaikan dengan kemampuan fasilitas belajar stake holder pendidikan (baik guru, orang tua, maupun peserta didik). Penggunaan media belajar berdasarkan dari hasil wawancara ${ }^{27}$ hanya menggunakan WA Group sebagai media komuikasi penyampaian materi pembelajaran baik berupa video, pdf, maupun penugasan yang dibantu dengan adanya buku paket sebagai buku pendamping. Sedangkan untuk pengambilan nilai Tes menggunakan google form dan untuk pengambilan nilai tugas mengerjakan lks dan kuis. Apabila ada yang peserta didik yang tidak memungkinkan untuk melakukan pembelajaran secara daring, maka dilakukan pembelajaran secara tatap muka muka di sekolah. Hal ini sesuai dengan pernyataan informan

"Ada sekitar 4-5 orang per kelas yang tidak bisa ikut daring karena keterbatasan ortu. Penyelasaian bagi yang tidak bisa pembelajaran daring, pembelajaran dilakukan si sekolah secara luring. atau gurumelakukan home visit ${ }^{28}$."

Berdasarkan pemaparan diatas, anilisis dampak yang dirasakan selama pelaksanaan BDR yaitu:

${ }^{26}$ Hasil wawancara dengan Ibu S M orang tua dari $\mathrm{T}$ (peserta didik kelas 5)

${ }^{27}$ Hasil wawancara dengan Pak SH, Pak M, Ibu S, Ibu S M, Ibu S W
1. Bagi Guru, dituntut untuk kreatif dalam penyampaian materi dengan memanfaatkan teknologi yang bisa diakses dan dimengerti oleh peserta didik. Apalagi dalam pelaksanaannya media yang digunakan hanya WA sehingga penyampaian materi tidak semaximal saat pembelajaran tatap muka.

2. Bagi Orang tua, memiliki kejenuhan dan kesulitan dalam mendampingi anak belajar karena ketidaksinkronan jadwal orangtua yang bekerja dengan jadwal BDR anak dan ada beberapa orang tua yang memiliki keterbatasan tidak bisa memfasilitasi anaknya menerapkan BDR.

3. Bagi Siswa, sulit memahami materi yang diberikan secara daring sehingga memiliki motivasi rendah dalam belajar dan mencari kegiatan lain yang sesuai dengan minatnya.

\section{B.2 Konstruksi Sosial Peserta Didik yang Bekerja}

Konstruksi sosial yang dimaksudkan Berger dan Luckman ${ }^{29}$ adalah kenyataan objektif, didalamnya terdapat adanya proses runtutan perubahan yang dibangun di atas pembiasaan. Terdapat perbuatan yang sering terjadi secara berulang sehingga terbentuk sebuah pola. Dengan begitu Berger dan Luckman berpandangan bahwa kenyataan itu hasil dari (eksternalisasi) dari internalisasi dan obyektifikasi manusia terhadap pengetahuan kehidupan sehari-hari.

\footnotetext{
${ }^{28}$ Hasil wawancara dengan Pak M

29 Sulaiman, "MEMAHAMI TEORI

KONSTRUKSI SOSIAL PETER L. BERGER.”
} 
Proses terjadinya peserta didik sebagai joki pemancing ikan dimulai dari kegiatan sekolah yang mulai dilakukan di rumah. Pelaksanaan BDR yang dilakukan di rumah membuat peserta didik tidak punya ruang kepada peserta didik untuk bercengkrama seperti biasa kepada teman temannya. Mereka awalnya memancing ikan hanya sebatas untuk senang-senang melepas penat sehabis BDR dan bosen di rumah. Didukung juga dengan lokasi Kolam Pancing yang dekat dari rumah peserta didik dan masih mempunyai hubungan saudara. Sehingga peserta didik kalau memancing digratiskan. "saya awalnya yaaa hanya melepas penat setelah belajar mbk, memancing disini, di rumah terus bosen." 30

Seiring berjalannya waktu, peserta didik tersebut memiliki skill sebagai pemancing ikan. Skill tersebut diperoleh dari kebiasaan mereka memancing ikan, sehingga lama-kelamaan skill mereka terasah dengan sendirinya. Dengan demikian hobi yang mereka jalani sebagai permainan menjadi sebuah keuntungan yang tak lain adalah mengasah skill, skill yang mereka peroleh yakni cara mendapatkan ikan, serta memilih pakan ikan yang dapat dijadikan sebagai umpan. Skill-skill yang diperoleh tersebut sudah dapat cukup menguntungkan. Seperti yang diungkapkan oleh salah satu informan

"hampir tiap hari memancing ikan, saya bisa cara memancing ikan biar mendapat ikan yang banyak. Awalnya yaa saya memancing ikan dengan menyentekkan stick biar dapat ikan, dengan cara itu bisa berhasil mendapat ikannya tetapi caranya salah. Karena kalau nyentek itu bisa menyakiti ikannya dan bisa

\footnotetext{
$3^{\circ}$ Hasil wawancara dengan A, peserta didik kelas 3 yang menjadi Joki Pemancing ikan lele
}

menyebabkan ikannya mati. Tetapi kalau sekarang bisa memancing dengan benar, agar bisa mendapat ikan caranya itu ada 3 mbak, pemilihan umpan nya, pemilihan tempat yang tepat sama cara mengangkat stick kalau ikannya udah makan umpannya." ${ }^{11}$.

Dari skill yang telah dimiliki tersebut lama-kelamaan mereka menjadikan skill mereka untuk memperoleh keuntungan. Keuntungan diperoleh dari mereka menjadi joki di pemancingan ikan, sehingga dari joki tersebut mereka mendapatkan upah yang dapat digunakan untuk keperluan sekolah mereka maupun untuk membantu orang tua. Upah yang di dapat pun nominalnya juga tidak konsisten, sehingga tidak ada jaminan pendapatan tetap bagi mereka. Seperti yang dikemukakan oleh informan sebagai berikut

"gara-gara saya kalau memancing sering mendapatkan ikan, ikannya saya kasihkan ke orang-orang yang belum mendapatkan ikan $m b$ karena kasihan. Sudah lama memancing ikan dan pasang umpan tetapi belum dapat. Dari situ saya mulai dikenal sama orang-orang pemancing disini dan diberi upah untuk memancingkan orang tersebut. Untuk pemberian upah nya ndak mesti mbak, ada yang hanya membayari mancingnya saja, ada yang membelikan makanan, ada yang memberi uang 5000. Tapi saya gitu doang sudah lumayan $m b$ dan sudah senang bisa memancing. Kalau ada lomba saya jadi yang penimbang ikan mba, lumayan

\footnotetext{
${ }^{31}$ Hasil wawancara dengan T, peserta didik kelas 5 yang menjadi Joki Pemancing ikan lele
} 
kadang sekali nimbang bisa dapat uang 5000 minimal"32

Awal mula menjadi joki pemancingan ikan para peserta didik lalai dalam menjalankan kewajibannya sebagai peserta didik yang tak lain adalah belajar. Namun, seiring berjalannya waktu peserta didik yang juga sebagai joki pemancingan ikan itu mulai memahami akan pentingnya membagi waktu antara Sekolah (BDR) dengan waktu joki memancing ikan. Hal tersebut merupakan perkembangan yang sangat baik, sehingga hobi memancing ikan tidak mengganggu kegiatan belajar mereka walaupun belajar dilakukan dengan cara daring. Hal ini diketahui dari pernyataan yang dilakukan oleh peserta didik yang mengungkapkan bahwa

"karena di pemancingan enak $m b$, tidak mikir. Yaa saya bolos, sekolahnya mama yang ngerjakan. Akan tetapi saya dimarahi mb, soalnya keterusan. Sampai sama mama dulu sempat melarang mancing lagi kalu tidak bisa bagi waktu. Tidak lama dari itu, saya bisa atur waktu antara belajar sama maemancing. Pembiasaanya sekolah dulu mbak kalau pagi, baru ketika sekolahnya sudah selesai saya ke pemancingan." 33

Kegiatan joki pemancingan ikan ini juga tidak ditentang oleh orang tua, karena sudah menjadi hobi dari anakanak mereka serta tempat pemancingan ikan ini juga tidak jauh sehingga masih dapat dipantau. Selain itu kegiatan joki ini juga tidak menggaggu waktu belajar mereka, hal ini malah menguntungkan bagi mereka sebagai penghasilan tambahan dan membantu dalam pembelian kuota internet yang

\footnotetext{
${ }^{32}$ Hasil wawancara dengan A dan T
}

dibutuhkan oleh peserta didik guna mengikuti pembelajaran secara daring (BDR). Disamping itu hobi yang mereka jalani ini justru malah mengasah skill memancing mereka yang nanti suatu saat dapat berguna bagi mereka.

Dilihat dari pandangan Berger dan Luckman proses eksternalisasai, objektivisasi dan internalisasi dapat ditelusuri dan dikaji bahwa $\mathrm{T}$ dan $\mathrm{A}$ yang merupakan joki pemancing ikan lele dapat dipandang sebagai kenyataan objektif, yang melakukan proses pembiasaan sebagai peserta didik untuk mengikuti pembelajaran dari rumah dan sebagai joki untuk membantu memancing ikan. Implementasi dari teori konstruksi sosial pada $\mathrm{T}$ dan $\mathrm{A}$ terlihat dari proses bagaimana awalnya mereka memancing dan melakukan pembelajaran dari rumah.

\section{SIMPULAN}

Pelaksanaan BDR pada semester ganjil masih belum optimal dikarenakan masih masa adaptasi bagi guru, orang tua maupun peserta didik. Dan sudah mulai berjalan dengan baik pada pelaksanaan pembelajaran semester genap dengan menggunakan acuan kurikulum darurat yang bisa disesuaikan dengan kemampuan dan kebutuhan sekolah. Dampak dari pelaksanaan BDR menyebabkan peserta didik jenuh di rumah dan mencari hobi baru di luar rumah, yaitu dengan memancing ikan. Penyaluran hobi baru yang ditekuni secara teratur membuat mereka mendapatkan skill, uang, dan pengalaman baru.

\section{DAFTAR PUSTAKA}

"Belajar Mandiri: Pembelajaran Daring Di Tengah Pandemi Covid-19 - Sri Gusty, Nurmiati Nurmiati, Muliana Muliana, Oris Krianto Sulaiman, Ni

33 Hasil wawancara dengan A dan T 
Luh Wiwik Sri Rahayu Ginantra, Melda Agnes Manuhutu, Andriasan Sudarso, Natasya Virginia Leuwol, Apriza Apriza, Andi Arfan Sahabuddin, Puji Hastuti, Akbar Yuli Setianto, Tia Metanfanuan, Lulu Jola Uktolseja, Jamaludin Jamaludin, Sherly Gaspersz, Karwanto Karwanto, Erni Rante Bungin, Samuel Y. Warella - Google Buku." Accessed March 1, 2021. https://books.google.co.id/books? $h l=i d \& l r=\& i d=H S z 7 D w A A Q B A J \& o i$ $=$ fnd \&pg $=$ PA85\&dq=kendala + pem belajaran+daring\&ots=QndJElBiNi \&sig=8NxfY1jzDChgHvcYGBLjotP QVU8\&redir_esc=y\#v=onepage\&q =kendala pembelajaran daring\&f=false.

Bell, Debora J., Mariella M. Self, Claytie Davis, Francine Conway, Jason J. Washburn, and Franci CrepeauHobson. "Health Service Psychology Education and Training in the Time of COVID-19: Challenges and Opportunities." American Psychologist, 2020. https://doi.org/10.1037/ampoooo67 3.

Daniel, Sir John. "Education and the COVID-19 Pandemic." Prospects, 2020.

https://doi.org/10.1007/s11125-02009464-3.

Hollweck, Trista. "Robert K. Yin. (2014). Case Study Research Design and Methods (5th Ed.). Thousand Oaks, CA: Sage. 282 Pages." The Canadian Journal of Program Evaluation, 2016.

https://doi.org/10.3138/cjpe.30.1.108

Ilmu, Jurnal, Agama Islam, Manajemen Kurikulum, Pendidikan Agama, Islam Jenjang, Pendidikan Dasar, : Kontekstualisasi, Strategi Pembelajaran, Semasa Pandemi, and Ayu Wilatikta. "J I A I." Ta'lim 2, no. 2 (October 30, 2020): 1-12. http://journal.uml.ac.id/TL/article /view/206.

CNN Indonesia. "Jokowi Imbau Masyarakat Bekerja Dan Beribadah Di Rumah,” 2020. https://www.cnnindonesia.com/na sional/20200315141316-32-

483586/jokowi-imbau-masyarakatbekerja-dan-beribadah-di-rumah.

Kemendikbud. "SE Mendikbud: Pembelajaran Secara Daring Dan Bekerja Dari Rumah Untuk Mencegah Penyebaran Covid-19." Kementerian Pendidikan dan Kebudayaan Republik Indonesia, 2020.

https://www.kemdikbud.go.id/mai n/blog/2020/o3/se-mendikbudpembelajaran-secara-daring-danbekerja-dari-rumah-untukmencegah-penyebaran-covidig.

"Kementerian Pendidikan Dan Kebudayaan » Republik Indonesia.” Accessed March 1, 2021. https://www.kemdikbud.go.id/mai n/blog/2020/o8/kemendikbudterbitkan-kurikulum-daruratpada-satuan-pendidikan-dalamkondisi-khusus.

Margaret, Poloma. "Sosiologi Kontemporer." Jakarta: PT. Raja Grafindo Persada, 2003.

Mutaqinah, Rina, and Taufik Hidayatullah. "Implementasi Pembelajaran Daring (Program BDR) Selama Pandemi Covid-19 Di Provinsi Jawa Barat." JURNAL PETIK, 2020. https://doi.org/10.31980/jpetik.v6i2 .869 .

Nasution, Inom, and Suharian Suharian. "PERAN ORANG TUA TERHADAP ANAK DALAM PROGRAM BELAJAR DARI RUMAH DI MASA PANDEMI COVID-19." Visipena, 
2020.

https://doi.org/10.46244/visipena.v 1112.1154 .

Pendidikan Administrasi Perkantoran, Jurnal, Oktafia Ika Handarini, and Siti Sri Wulandari. "Pembelajaran Daring Sebagai Upaya Study From Home (SFH) Selama Pandemi Covid 19." Jurnal Pendidikan Administrasi Perkantoran (JPAP). Vol. 8, July 17, 2020. https://journal.unesa.ac.id/index.p hp/jpap.

Pratiwi, Indah, and Bakti Utama. "KESENJANGAN KUALITAS LAYANAN PENDIDIKAN DI INDONESIA PADA MASA DARURAT COVID-19: TELAAH DEMOGRAFI ATAS IMPLEMENTASI KEBIJAKAN BELAJAR DARI RUMAH.” Jurnal Kependudukan Indonesia, 2020. https://doi.org/10.14203/jki.voio.53 9.

Rigianti, Henry Aditia. "KENDALA PEMBELAJARAN DARING GURU SEKOLAH DASAR DI BANJARNEGARA." Elementary School: Jurnal Pendidikan Dan Pembelajaran Ke-SD-An 7, no. 2 (July 1, 2020): 297-302. https://doi.org/10.31316/esjurnal.v7 i2.768.

Satgas Covid-19. "Kilas Balik Pandemi Covid-19 Di Indonesia.” CNN Indonesia, November 2020. https://www.cnnindonesia.com/na sional/20201110123516-25- 568018/kilas-balik-pandemi-covid19-di-indonesia.

Siahaan, Matdio. "Dampak Pandemi Covid-19 Terhadap Dunia Pendidikan." Jurnal Kajian Ilmiah, 2020.

https://doi.org/10.31599/jki.v1i1.265

Sulaiman, Aimie. "MEMAHAMI TEORI KONSTRUKSI SOSIAL PETER L. BERGER.” Society, 2016. https://doi.org/10.33019/society.v4i 1.32 .

Wardani, Anita, and Yulia Ayriza. "Analisis Kendala Orang Tua Dalam Mendampingi Anak Belajar Di Rumah Pada Masa Pandemi Covid19." Jurnal Obsesi : Jurnal Pendidikan Anak Usia Dini, 2020. https://doi.org/10.31004/obsesi.v5i1 .705 .

\section{Wawancara}

Pak M, (Kepala sekolah MI) wawancara oleh Ervi Revilda 17 April 2021

Pak SH (Waka Kurikulum) wawancra oleh Ervi Revilda 21 April 2021

$\mathrm{Bu}$ S, (salah satu guru di MI) wawancara oleh Ervi Revilda 26 Februari 2021

Bu S M, (orang tua T) wawancara oleh Ervi Revilda 20 Februari 2021

Bu S W, (orang tua A) wawancra oleh Ervi Revilda 20 Februari 2021

$\mathrm{T}$, (peserta didik kelas 5 dan joki) wawancara oleh Ervi Revilda 20 februari 2021

A, (peserta didik kelas 3 dan joki) wawancara oleh Ervi Revilda 20 februari 2021 